\title{
LAYANAN PUSTAKA ISLAM BERBASIS DIGITAL
}

\author{
Habiba Nur Maulida \\ Fakultas Ilmu Sosial \\ Ilmu Perpustakaan Universitas Islam Negeri Sumatera Utara \\ Email: habiba_nurmaulida@yahoo.co.id
}

\begin{abstract}
Abstrak
Perpustakaan lahir pada masa kejayaan Islam yang merupakan sarana untuk belajar atau tempat untuk memperoleh ilmu pengetahuan. Lahirnya perpustakaan di dunia Islam membuat umat Islam dapat membangun peradaban dan kejayaannya yang bertahan beberapa abad lamanya. Seiring dengan perkembangan zaman adanya ledakan informasi yang menuntut pada perubahan yang cepat dan nyata, karena hal ini juga berdampak pada tuntutan perpustakaan yang harus berubah sesuai dengan perkembangan teknologi informasi. Salah satu alternatif yang layak dikembangkan dalam memberikan kemudahan, kecepatan, dan ketepatan dalam akses informasi kepada pengguna perpustakaan adalah dengan mengembangkan layanan berbasis web yang dihubungkan dengan media sosial seperti Al-Maktabah Al-Syamilah. Al-Maktabah Al-Syamilah adalah software perpustakaan Islam berbasis digital yang memiliki koleksi yang lengkap dan mudah diakses.
\end{abstract}

Kata Kunci: Layanan Perpustakaan, Perpustakaan Digital, Islam

\begin{abstract}
The library was born during the heyday of Islam which was a means of learning or a place to gain knowledge. The birth of libraries in the Muslim world allowed Muslims to build their civilization and glory that lasted for several centuries. Along with the development of the era of an explosion of information that demands rapid and real changes, because this also has an impact on the demands of libraries that must change in accordance with the development of information technology. One alternative that is feasible to be developed in providing convenience, speed, and accuracy in accessing information to library users is to develop web-based services that are linked to social media such as Al-Maktabah AlSyamilah. Al-Maktabah Al-Syamilah is a digital based Islamic library software that has a complete and easily accessible collection. Keyword: Library Services, Digital Library, Islamic
\end{abstract}




\section{A. Pendahuluan}

Pada masa kejayaan Islam, perpustakaan merupakan sarana untuk belajar yang pada akhirnya umat Islam dapat membangun peradaban dan kejayaannya yang bertahan beberapa abad lamanya. Banyak informasi dan ilmu pengetahuan yang tidak terdokumentasikan dengan baik oleh umat Islam dilupakan begitu saja. Akibatnya tatanan umat Islam baik aspek ekonomi, politik, sosial, budaya dan aspek kehidupan yang lain mengalami stagnasi. Sehingga akhirnya umat Islam hanya menjadi umat pengikut dari bangsa maju, yang dalam hal ini adalah dunia barat. Padahal kita menyadari bahwa kemajuan dunia barat dicapai dengan melalui penguasaan ilmu pengetahuan yang di ambil dari pusat-pusat ilmu pengetahuan muslim seperti perpustakan.

Dari paparan di atas menunjukan betapa pentingnya perpustakaan dalam pengembangan suatu bangsa. Dalam hal ini banyak ilmu pengetahuan, informasi dan dokumentasi yang di sediakan perpustakaan memiliki peran yang sangat besar dalam pemberdayaan umat. Banyak literatur yang mengungkapkan bahwa perpustakaan sebagai tempat aktivitas belajar, yang kegiatannya hampir sama dengan apa yang di lakukan di sekolahsekolah. Fungsi dan peran perpustakaan ini banyak di adopsi oleh perpustakaan di negara maju seperti Inggris, Australia dan Kanada. Banyak perpustakaan di ubah menjadi learning center atau resources center. Hal ini mengidentifikasikan bahwa perpustakaan yang di perankan pada masa kejayaan Islam sangat penting dan representatif untuk pengembangan dan memajukan masyarakat. 


\section{B. Sejarah Perpustakaan Islam}

Praktik kepustakawanan yang berupa tradisi penulisan dan pelestarian informasi dalam suatu media tertentu sebenarnya telah berkembang sejak kelahiran Islam, yaitu berupa penulisan wahyu Al-Qur'an, dan pelestariannya dalam media penyimpan informasi seperti kulit binatang, batu, daun, dan lain-lain. Muhammad Saw., sangat memperhatikan terhadap perlunya menyimpan dan melestarikan dokumen. Selain untuk keperluan pencatatan wahyu, nabi juga membuat catatan-catatan tertulis sebagai bagian dari kegiatan administrasi. Meskipun demikian, pada periode ini tidak ditemukan tempat khusus yang berfungsi sebagai suatu perpustakaan. Perpustakaan baru tumbuh pada masa Daulah Bani Umayyah.

\section{Masa Perintisan Perpustakaan}

Menurut Undang-Undang Republik Indonesia Nomor 43 Tahun 2007 Perpustakaan adalah institusi pengelola koleksi karya tulis, karya cetak, dan atau karya rekam secara profesional dengan sistem yang baku guna memenuhi kebutuhan pendidikan, penelitian, pelestarian, informasi, dan rekreasi para pemustaka. Pada masa Nabi Muhammad Saw., dan para sahabatnya, perpustakaan dalam pengertian di atas tidak di temukan. Akan tetapi cikal bakal atau rintisan perpustakaan sudah ada, yaitu sebagai berikut:

1. Wahyu Allah yang pertama kepada Nabi Muhammad Saw., ialah perintah kepada umat Islam untuk membaca (Iqra).

2. Rasulullah Saw., mengangkat para sahabatnya, antara lain: Zaid bin Tsabit, Ubay bin Ka'ab, dan Khalid bin Walid sebagai penulis Al-Qur'an.

3. Perintah Rasulullah Saw., kepada tawanan perang Badar untuk mengajari anak-anak Muslim membaca dan menulis. 
4. Pada masa Rasulullah Saw., muncul keinginan menulis AlQur'an dalam bentuk mushaf pribadi seperti Mushaf Ubay bin Ka'ab, Mushaf Ibnu Mas'ud, Mushaf Ibn Abbas dan pada ahirnya melahirkan Mushaf Utsmani yang di salin menjadi 4 Mushaf. Tetapi riwayat lain menyebutkan lima salinan di sebarkan ke kota Madinah, Makkah, Kuffah, Basrah dan Damaskus. Mushaf-mushaf tersebut di jadikan referensi oleh Umat Islam. Peristiwa diatas mendorong umat Islam gemar menulis dan membaca.

\section{Masa Pembentukan dan Pembinaan Perpustakaan}

Ada beberapa hal yang melatar belakangi pembentukan dan pembinaan perpustakaan, antara lain:

1. Setelah Al-Qur'an di kodifikasi dalam bentuk mushaf timbul keinginan masyarakat muslim, terutama yang hidup jauh dari masa Rasulullah SAW untuk memahami Al-Qur'an dan ajaran-ajaran Islam sesuai dengan yang di pahami dan dilaksanakan oleh Rasulullah SAW. Pada masa Umar bin Abdul Aziz (wafat $675 \mathrm{M}$ ) beliau dengan otoritasnya memerintah Muhammad bin Muslim bin Syihab az-Zuhri alMadani (wafat $695 \mathrm{M}$ ) untuk menghimpun hadits dan menulisnya dalam sebuah buku. Kemudian hadits-hadits tersebut ditulis dan disebarluaskan ke penjuru negeri untuk di jadikan referensi.

2. Kepeloporan Ibn Syihab az-Zuhri di ikuti oleh ulama-ulama lainnya. Pada masa itu hadits menjadi primadona. Banyak ahli hadits yang rela melakukan perjalanan jauh dan melelahkan hanya demi mendapatkan sebuah hadits dan kemudian dihimpun dalam koleksi mereka masing-masing. Akhirnya dikenal dengan koleksi Sahih Bukhari, Sahih Muslim, Sunan Abu Daud, Sunan at-Turmudzi, dan koleksi- 
koleksi lainya. Setiap koleksi bisa terdiri dari tiga jilid atau lebih bahkan sampai belasan jilid, sehingga menambah bahan rujukan Islam.

3. Gerakan penerjemahan yang di pelopori oleh Khalifah alMansur dari Daulah Abbasiyah telah membantu dalam penambahan jumlah koleksi pustaka pada waktu itu. Dia memperkejakan orang-orang Persia yang baru masuk Islam untuk menterjemahkan karya-karya berbahasa Persia dalam bidang astrolgi, ketatanegaraan dan politik, moral, seperti Kalila wa Dimmadan Sindhid di terjemahkan ke dalam bahasan Arab. Selain itu, di terjemahkan dari bahasa Yunani seperti Logika karya Aristoteles, lmagest karya Ptolemy, Arithmetic karya Nicomashus, Geometri karya Euclid.

Bahan pustaka yang cukup banyak tadi berupa mushaf AlQur'an maupun hadits dan karya-karya terjemahan mendorong penguasa pada waktu itu untuk mendirikan perpustakaan. Perpustakaan yang resmi berdiri pertama kali untuk publik adalah Baitul Hikmah. Perpustakaan itu bukan saja berfungsi sebagai tempat penyimpanan buku, tetapi sebagai pusat pengembangan ilmu pengetahuan. Pada masa Harun al-Rasyid institusi perpustakaan bernama Khizanah al Hikmah berfungsi sebagai perpustakaan dan pusat penelitian.

Sejak tahun $815 \mathrm{M}$, al-Makmun mengembangkan Lembaga itu dengan mengubah namanya menjadi Bait al-Hikmah. Pada masa itu Bait al-Hikmah digunakan secara lebih maju, yaitu sebagai tempat penyimpanan buku-buku kuno yang di dapat dari Persia, Bizantium, Etiopia, dan India. Direktur perpustakaannya adalah seorang nasionalis persia dan ahli Pahlevi, yaitu Sahl ibn Harun. Pada masa al-Makmun, Bait al-Hikmah ditingkatkan lagi 
fungsinya menjadi pusat kegiatan studi, riset astronomi dan matematika.

\section{Faktor-faktor yang Berpengaruh terhadap Perkembangan Perpustakaan}

Perkembangan perpustakaan di dunia Islam mencapai puncaknya terjadi pada masa kekuasaan Bani Abbas atau Daulah Abbasiyyah. Berbeda dengan masa pemerintahan kekhalifahan Bani Umayyah, yakni kebijakan pemerintah lebih banyak diorientasikan pada pengembangan wilayah kekuasaan dan pembangunan infrastruktur kepemerintahan. Selain itu, adanya berbagai konflik dari kalangan atau kelompok-kelompok yang tidak setuju dengan pemerintahannya, yang menyebabkan upaya pengembangan ilmu pengetahuan tidak diperhatikan seperti kelompok Syi'ah, golongan Khawarij.

Sedangkan pada masa kekhalifahan Daulah Abbasiyyah, tradisi ilmiah dan ilmu pengetahuan berkembang demikian pesat sehingga kebijakan pemerintah lebih mendorong tumbuhnya pusat-pusat studi ilmu pengetahuan termasuk perpustakaan. Pada masa ini masyarakat hidup dalam kesejahteraan dan ilmu pengetahuan mencapai tingkat kemajuan yang membanggakan. Perkembangan perpustakaan tidak semata-mata sebagai tempat penyimpanan buku-buku, tetapi lebih dari itu yakni perpustakaan merupakan pusat belajar, pusat penelitian, dan pusat kegiatan ilmiah lainnya.

\section{Kemunduran dan Kehancuran Perpustakaan}

Kemunduran dan kehancuran perpustakaan di era peradaban Islam mengikuti kejatuhan wilayah-wilayah muslim setelah pertarungan fisik melawan musuh-musuhnya. Misalnya perpustakaan di Tripoli di hancurkan oleh tentara perang Salib 
atas komando seorang rahib yang tak senang saat melihat banyak Al Qur'an di perpustakaan tersebut. Di samping itu perpustakaan terkenal lainnya, seperti milik Sultan Nuh Ibn Mansur yang dibakar setelah filosuf besarnya menyelesaikan penelitiannya di tempat itu. Kenyataan itu menimbulkan tuduhan bahwa cendikiawan sendiri yang membakar perpustakaan setelah menguasai isi keilmuan yang terkandung dalam perpustakaan tersebut. Peristiwa lainnya terjadi pada tahun $1258 \mathrm{M}$ ketika sekelompok bangsa Mongol dan Tartar menjarah kota Baghdad dan membakar perpustakaannya.

Ada beberapa faktor yang menjadi penyebab kemunduran perpustakaan, antara lain:

\section{Serangan Tentara Salib}

Perpustakaan di Tripoli di hancurkan melalui serangan dan pembakaran oleh tentara perang Salib atas komando seorang rahib yang tak senang saat melihat banyak AlQur'an di perpustakaan tersebut. Kehilangan koleksi bukubuku diperkirakan mencapai jumlah sekitar tiga juta buah.

\section{Invansi Pasukan Tartar terhadap Negeri-negeri Islam}

Serangan pasukan Tartar atau bangsa Mongol ke wilayahwilayah Islam telah menjadi salah satu penyebab utama kehancuran perpustakaan. Mereka membuang seluruh buku-buku yang terdapat di perpustakaan umum ke sungai Dajlah, sehingga sungai tersebut penuh dengan buku-buku.

3. Konflik Internal di Kalangan Umat Muslim

Tertara Turki yang menyerang khalifah Fatimiyah di Kairo telah menghancurkan perpustakaan al-Hakim dengan membuang buku-bukunya ke sungai Nil, merobek-robek dan 
membakar isi buku. Sebagian dari mereka mengambil sampul-sampul buku untuk dijadikan sandal yang mereka pakai. Koleksi tersebut dimusnahkan karena banyak yang bertentangan dengan mazhab ahli sunnah.

\section{Persoalan Pribadi atau Keluarga}

Kecemburuan dan kekecewaan atas sikap seorang suami telah membawa petaka bagi nasib perpustakaanperpustakaan, terutama perpustakaan khusus. Hal ini terjadi karena orang-orang di kalangan umat Islam sangat gemar membaca buku. Mereka mencintai buku melebihi dari diri dan keluarganya, sehingga banyak istri yang merasa diabaikan.

Demikianlah umat Islam berkembang dengan pesat pada awalnya seiring dengan perkembangan perpustakaan dan mundurnya umat Islam bersamaan dengan mundurnya perpustakaan. Dengan demikian cara untuk memajukan peradaban umat Islam adalah salah satunya dengan memajukan perpustakaan yaitu dengan membina perpustakaan dan meningkatkan kesadaran umat Islam akan pentingnya ilmu pengetahuan yang terkandung di dalamnya.

\section{E. Perpustakaan Digital}

Adanya ledakan informasi menuntut perpustakaan untuk menyediakan layanan yang berbasis digital agar setiap orang mudah untuk memperoleh informasi secara cepat dan tepat. Informasi tersebut juga bisa diakses dimana saja dan kapan saja tanpa melihat ruang dan waktu. Perpustakaan digital adalah sebuah sistem elektronik perpustakaan yang memudahkan akses informasi dalam bentuk digital yang didalamnya terdapat staff dengan keahlian khusus untuk menyebarluaskan informasi 
melalui jaringan internet. Perpustakaan digital bertujuan untuk membuka akses seluas-luasnya terhadap informasi yang sudah dipublikasikan.

Komponen yang harus ada di dalam perpustakaan digital, antara lain :

1. Sumber informasi digital (digital resources)

Terdiri dari koleksi digital atau form elektronik berupa teks, grafik, audio-video, program-program komputer, dan lainlain.

2. Teknologi infrastruktur (technological infrastructure)

Perpustakaan digital mengintegrasikan kegiatan komputasi, penyimpanan dan teknologi komunikasi secara bersamasama dengan alat lain dan teknik-teknik untuk mengoperasikan dan memelihara jaringan sistem informasi digital. Teknologi infrastruktur meliputi perangkat keras, perangkat lunak, dan jaringan komputer.

3. Pengalaman (experience) dan petugas yang ahli (expertise)

Faktor manusia juga memberikan prioritas dalam mendesain, membangun, mengorganisir, mengelola, dan mengoperasikan sistem perpustakaan digital. Pengalaman dan keahlian yang dibutuhkan dalam perpustakaan digital meliputi pengetahuan, keterampilan, kompetensi, dan kapabilitas petugas perpustakaan dan sumber daya manusia lain yang berhubungan dengan sumber-sumber digital, teknologi digital, dan desain sistem serta promosi pelayanan.

4. Pelayanan perpustakaan digital (digital library services)

Sistem perpustakaan digital, manusia, proses dan teknologi bekerja bersama-sama memberikan kepuasan kepada kebutuhan pengguna dimana saja dan setiap saat. 
Perpustakaan digital berinteraksi dengan sumber-sumber digital, sistem organisasi pengetahuan dan pengguna.

\section{F. Layanan Perpustakaan Digital}

Pelayanan perpustakaan digital meliputi:

1. Akses yang terintegrasi kepada sumber-sumber informasi online. Pengambilan informasi secara online meliputi: akses, browsing, dan fasilitas-fasilitas pencarian.

2. Akses secara elektronik ke database bibliometrik (di dalam dan di luar perpustakaan)

3. Akses elektronik pada jurnal dan buku secara full-text

4. Pelayanan referens secara elektronik

5. Pelayanan inter-library loan, yang meliputi: permintaan secara online terhadap dokumen-dokumen.

6. Sharing jaringan dan sumber pustaka

7. Publikasi elektronik

8. Pelatihan pengguna menggunakan perpustakaan digital, dll.

\section{G. Layanan Perpustakaan Islam Berbasis Digital}

Layanan perpustakaan Islam berbasis digital merupakan layanan yang disediakan oleh perpustakaan-perpustakaan Islam kepada pengguna perpustakaan yang dapat diakses secara digital. Adapun layanan perpustakaan Islam berbasis digital tersebut adalah sebagai berikut.

\section{Digital Library UIN-SU}

Diakses melalui http://digilib.uinsu.ac.id/

Layanan OPAC

Layanan OPAC (Online Public Access Catalogue) atau yang biasa disebut katalog merupakan alat untuk menemukan keberadaan koleksi di perpustakaan tersebut. Alat ini dapat 
mempermudah pengguna perpustakaan untuk mencari koleksi yang dibutuhkan.

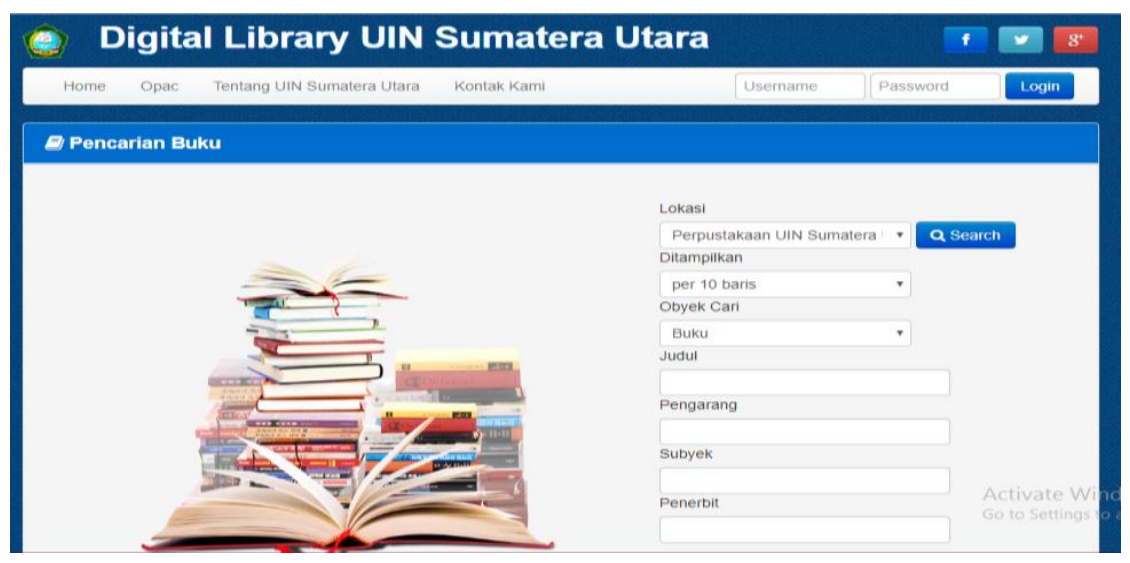

\section{Layanan Repository}

Repository adalah tempat penyimpanan dan penyebarluasan informasi atau materi yang diterbitkan oleh institusi induknya. Layanan repository ini dapat diakses melalui http:/ / repository.uinsu.ac.id/

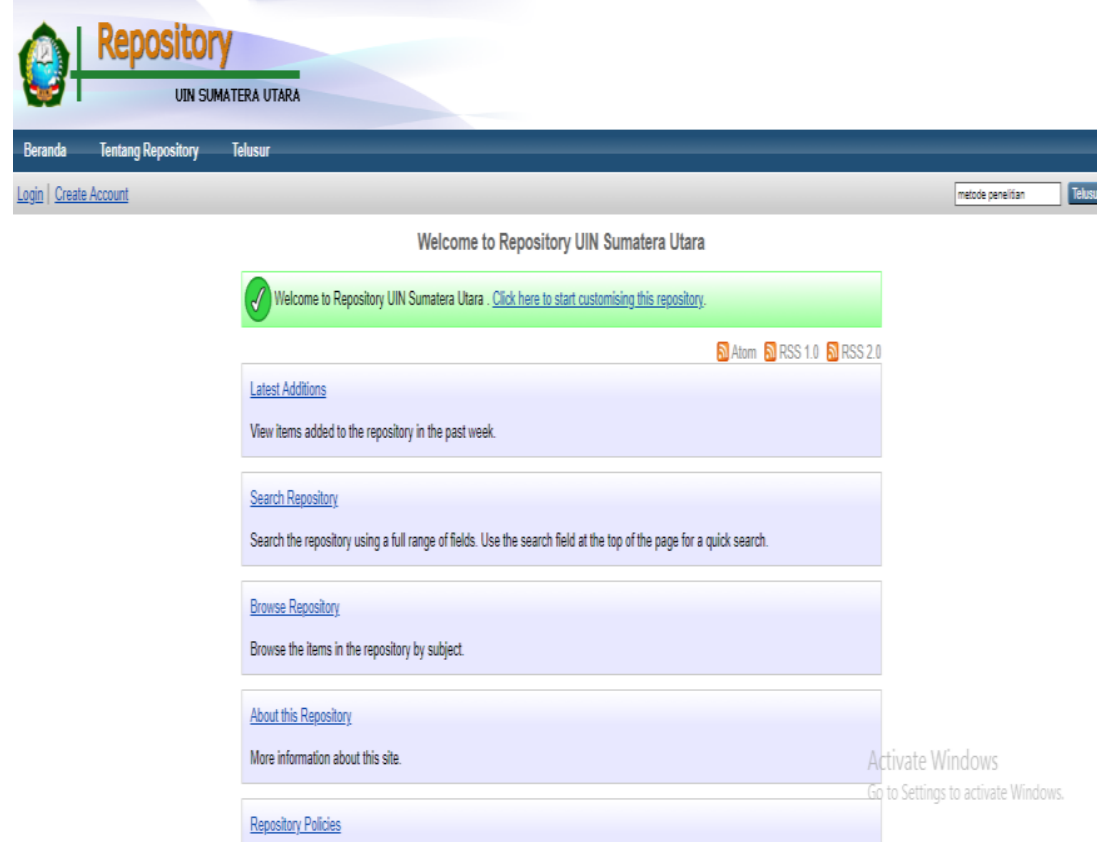




\section{Layanan E-journal}

Journal merupakan wadah/tempat artikel yang telah melalui proses penyuntingan dan penelaahan sehingga mudah diakses, dibaca, dan ditelusuri. Di Perpustakaan UIN-SU sudah menyediakan layanan jurnal yang berbasis digital. Layanan e-journal ini dapat diakses melalui http:/ /jurnal.uinsu.ac.id/index.php/iqra

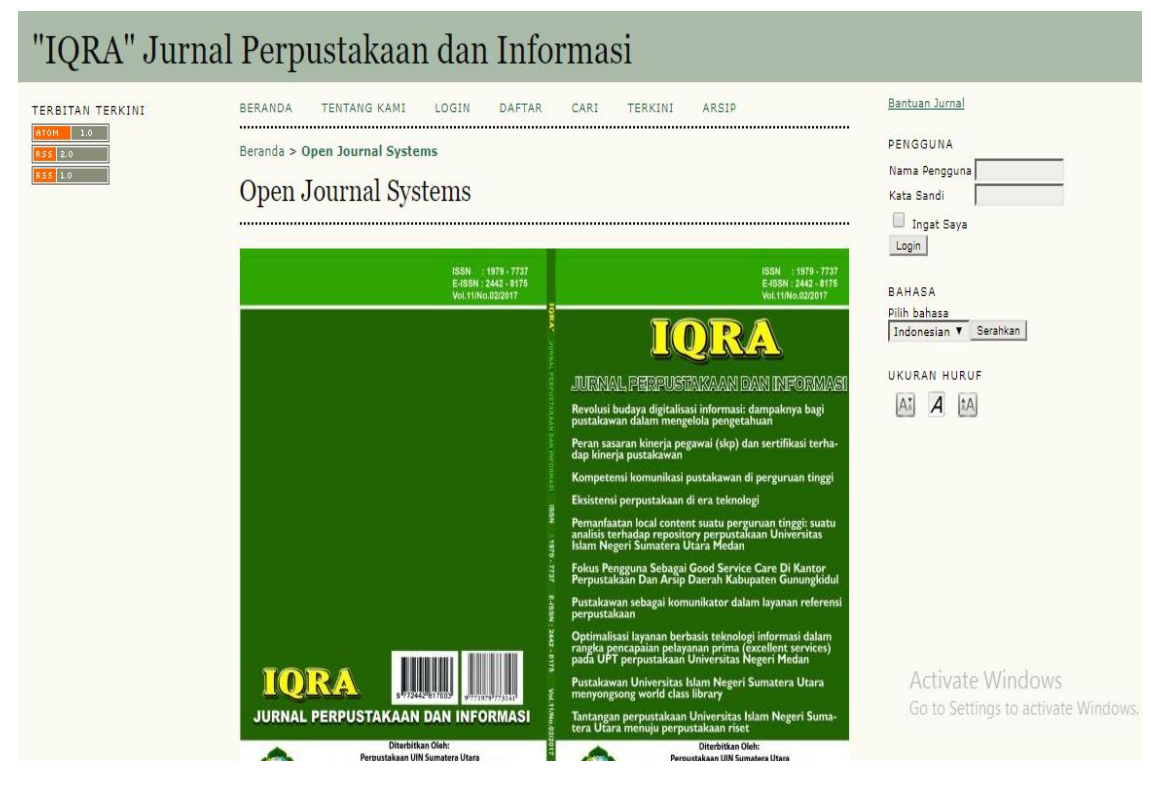

\section{$\underline{\text { KUBUKU }}$}

KUBUKU merupakan aplikasi digital yang disediakan oleh perpustakaan yang telah melakukan kerjasama dengan pihak KUBUKU. Aplikasi ini berisi buku-buku yang ada di perpustakaan. Pengguna bisa menemukan buku-buku yang diinginkan melalui aplikasi ini. Buku-buku yang ada di dalam aplikasi ini juga bisa dibaca dan dipinjam oleh pengguna perpustakaan. Aplikasi KUBUKU ini dapat diakses melalui https://kubuku.id/download/perpustakaan-uinsumatera-utara/ 


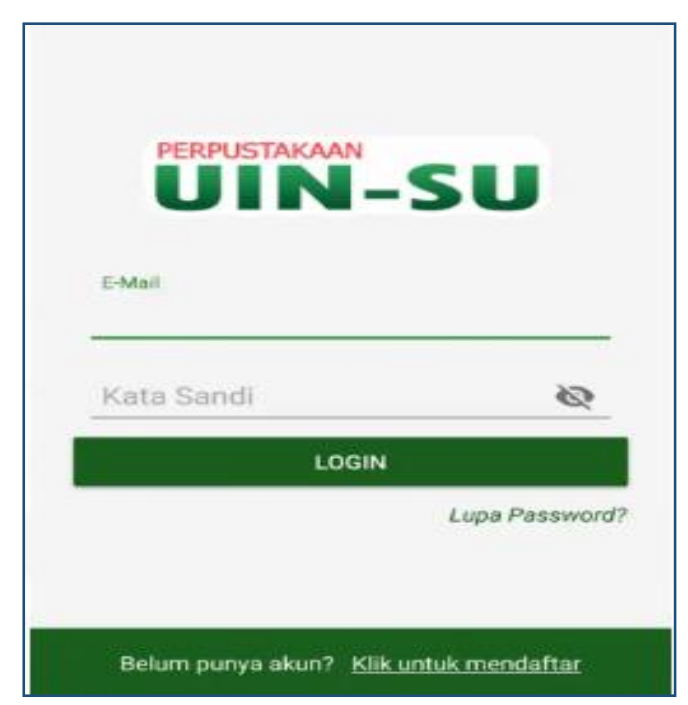

Cara mendaftar kubuku:

- Buka aplikasi Perpustakaan Digital UINSU

- Isi pendaftaran

- Klik OK

- $\quad$ Klik link e-mail

\section{Perpustakaan Digital UIN Syarif Hidayatullah}

Diakses melalui http://www.perpus.uinjkt.ac.id/ $\underline{\text { Layanan OPAC }}$

Layanan OPAC (Online Public Access Catalogue) atau yang biasa disebut katalog merupakan alat untuk menemukan keberadaan koleksi di perpustakaan tersebut. Alat ini dapat mempermudah pengguna perpustakaan untuk mencari koleksi yang dibutuhkan. Layanan OPAC ini dapat diakses melalui http://tulis.uinjkt.ac.id/ 
Pusat Perpustakaan UIN Syarif Hidayatullah Jakarta Knowedge, Piety, Integrity

\section{h manuage}

Q Search

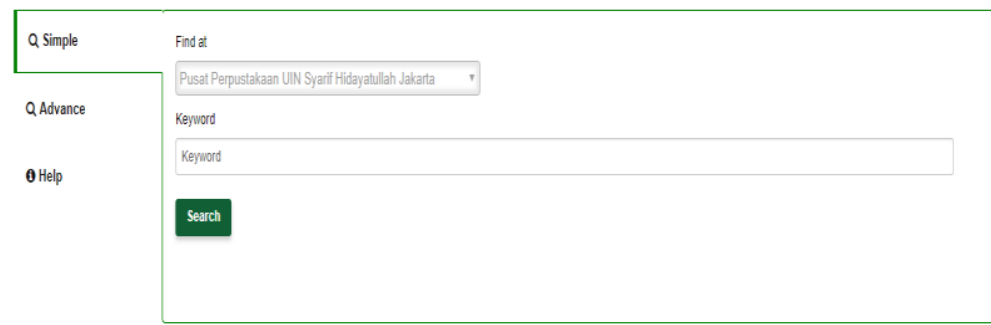

틀Dokumen

I Buk $(42510)$

\section{Layanan E-journal}

Journal merupakan wadah/tempat artikel yang telah melalui proses penyuntingan dan penelaahan sehingga mudah diakses, dibaca, dan ditelusuri. Di Perpustakaan UIN Syarif Hidayatullah Jakarta sudah menyediakan layanan jurnal yang berbasis digital. Layanan e-journal ini dapat diakses melalui http://journal.uinjkt.ac.id/index.php/al-maktabah

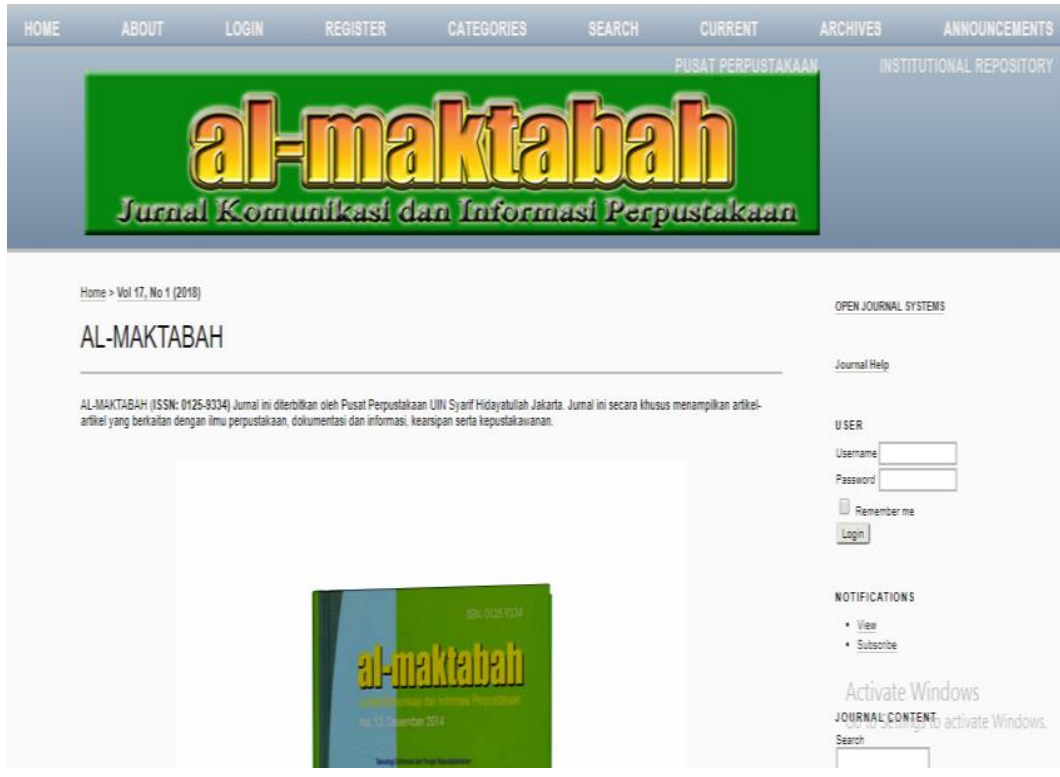




\section{Layanan Repository}

Repository adalah tempat penyimpanan dan penyebarluasan informasi atau materi yang diterbitkan oleh institusi induknya. Layanan repository ini dapat diakses melalui http://repository.uinjkt.ac.id/dspace/

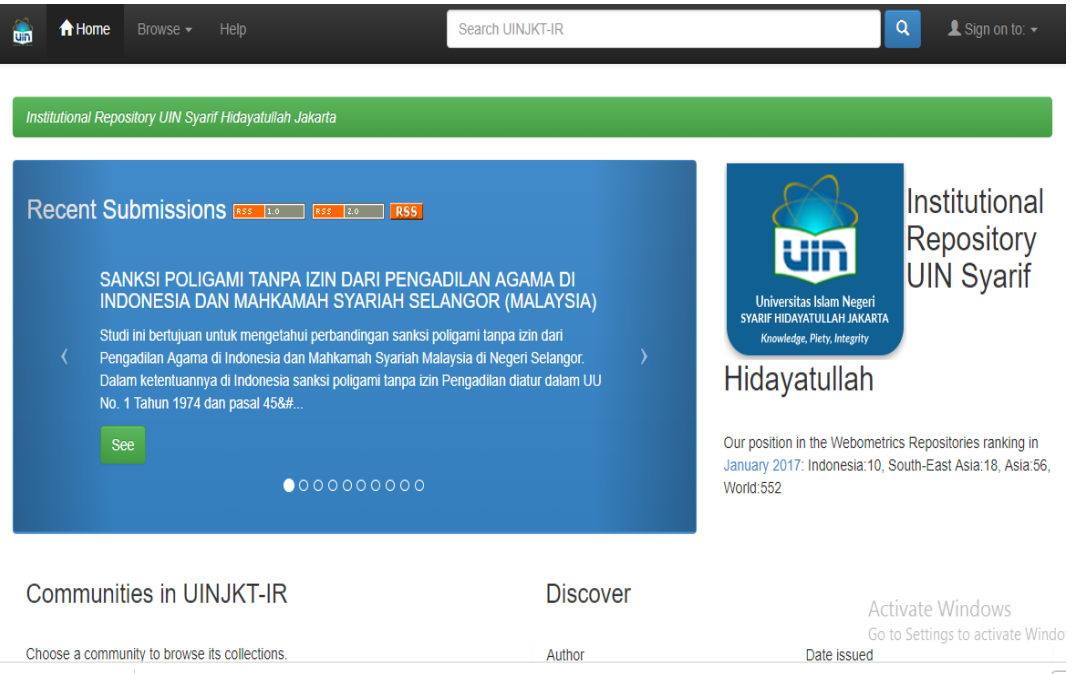

\section{Layanan E-book}

Layanan e-book merupakan layanan yang disediakan perpustakaan berupa buku elektronik yang dapat diakses secara digital. Layanan e-book ini dapat diakses melaui http://perpus.uinjkt.ac.id/content/e-book

\begin{tabular}{|c|c|c|}
\hline \multicolumn{3}{|c|}{$\begin{array}{l}\text { KOLEKSI E-BOOK } \\
\text { UNIVERSITAS ISLAM NEGERI SYARIF HIDAYATULLAH JAKARTA } \\
2018\end{array}$} \\
\hline NO & NAMA PENERBIT & JUMLAH \\
\hline 1 & Brill & 237 judul \\
\hline 2 & Cambridge University Press & 581 judul \\
\hline 3 & Emerald Group Publishing & 120 judul \\
\hline 4 & Gale Virtual Reference Library & 32 judul \\
\hline 5 & IGPublishing & 2752 judul \\
\hline 6 & Oxford University Press & 198 judul \\
\hline 7 & EBSCO & 62 judul \\
\hline \multirow[t]{2}{*}{8} & Wiley & 35 judul \\
\hline & Jumlah & 4017 judul \\
\hline
\end{tabular}




\section{H. Software yang Digunakan dalam Perpustakaan Islam Berbasis Digital}

Salah satu software yang digunakan dalam perpustakaan Islam berbasis digital adalah al-Maktabah al-Syamilah. AlMaktabah al-Syamilah merupakan perpustakaan yang lengkap karena terdapat ribuan koleksi kitab yang terkumpul di dalamnya. Software Al-Maktabah al-Syamilah ini juga mudah dikelola, cara penggunaannya praktis dan biayanya murah. Informasi yang terdapat dalam setiap kitab pada software ini sangat mudah diakses. Selain itu, penggunaan software Al-Maktabah al-Syamilah dapat menghemat waktu dalam pencarian informasi dalam kitabkitab tersebut.

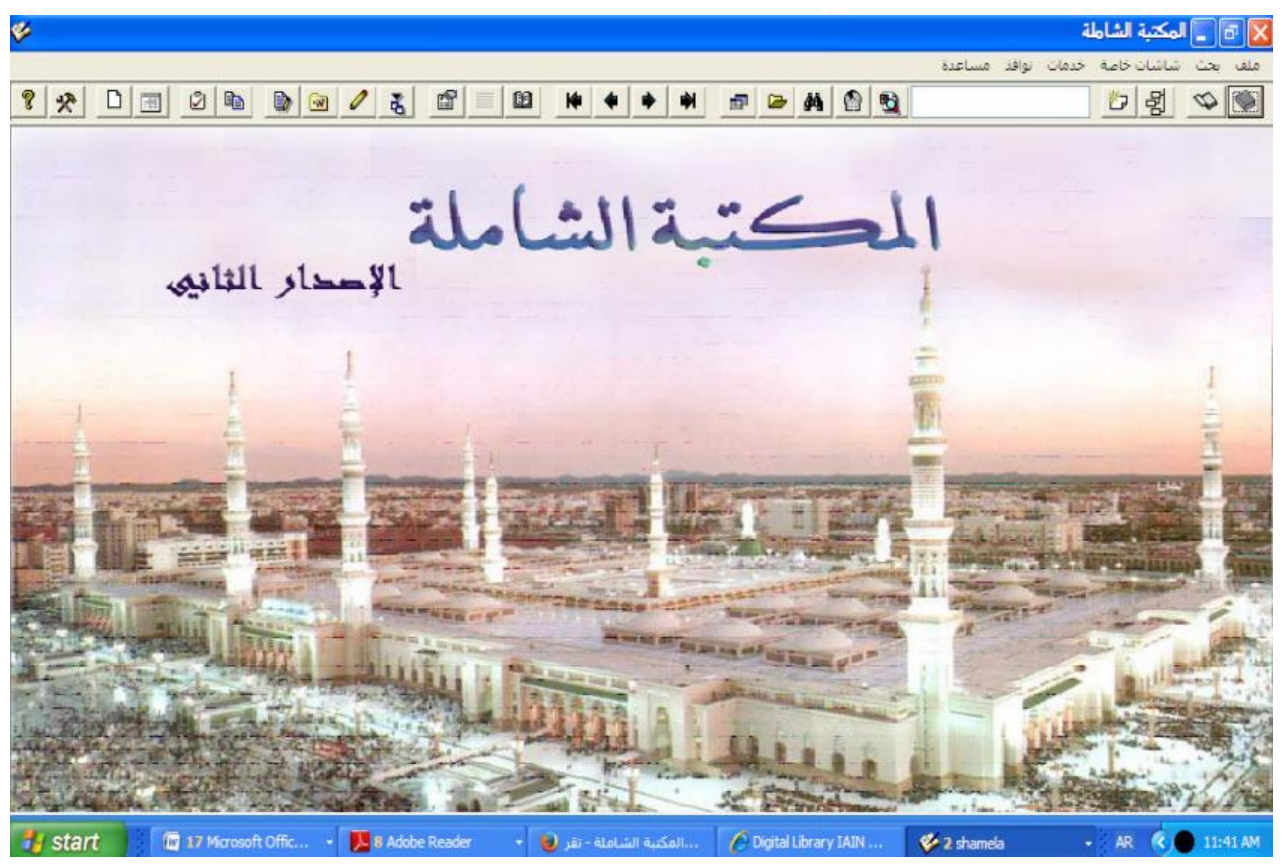

Tampilan Utama al-Maktabah al-Syamilah

Ada beberapa kelebihan software al-Maktabah Al-Syamilah, antara lain:

- Efisiensi waktu dan biaya

- Kecepatan dalam pencarian informasi tentang isu-isu yang diinginkan 
- Fleksibelitas

Selain itu, software al-Maktabah Al-Syamilah juga memiliki kekurangan, antara lain:

- Terkadang ada ketidakcocokan nomor halaman versi digital dengan versi cetaknya

- Membuat orang malas untuk membaca semua informasi dalam kitab

- Fasilitas pencarian bisa jadi tidak sufficient

\section{KESIMPULAN}

Perpustakaan lahir pada masa kejayaan Islam yang merupakan sarana untuk belajar atau tempat untuk memperoleh ilmu pengetahuan. Lahirnya perpustakaan di dunia Islam membuat umat Islam dapat membangun peradaban dan kejayaannya yang bertahan beberapa abad lamanya. Seiring dengan perkembangan zaman adanya ledakan informasi yang menuntut pada perubahan yang cepat dan nyata, karena hal ini juga berdampak pada tuntutan perpustakaan yang harus berubah sesuai dengan perkembangan teknologi informasi. Salah satu alternatif yang layak dikembangkan dalam memberikan kemudahan, kecepatan, dan ketepatan dalam akses informasi kepada pengguna perpustakaan adalah dengan mengembangkan layanan berbasis web yang dihubungkan dengan media sosial seperti Al-Maktabah Al-Syamilah. Al-Maktabah Al-Syamilah adalah software perpustakaan Islam berbasis digital yang memiliki koleksi yang lengkap dan mudah diakses. 


\section{DAFTAR PUSTAKA}

Aris, Nur. Digital Library: Mengenal Al-Maktabah Al-Syamilah. Jurnal Libraria. Retrieved

From:

http://journal.stainkudus.ac.id/index.php/Libraria/article/downl oad/1589/1458

pada 1 Mei 2019

Kurniawan, Agus Yazid. (2016). Pengelolaan Perpustakaan Digital di SMA Negeri 1

Yogyakarta. Skripsi. Universitas Negeri Yogyakarta. Retrieved From:

https: / / eprints.uny.ac.id/40568/1/Agus\%20Yazid\%20Kurnia wan_09101244017.pdf

pada 5 Oktober 2019

Rifai, Agus. (2014). Perpustakaan Islam: Konsep, Sejarah, dan Kontribusinya dalam

Membangun Peradaban Islam Masa Klasik. Jakarta: Rajawali Pers.

Rozen, Minna. (2010). A History of the Jewish Community in Istanbul The Formative Years,

1453-1566. Leiden: Koninklijke Brill NV.

Retrieved From: https://doi.org/10.1163/9789004215726 pada 1 Mei 2019

Saifuddin. (2016). Strategi Pengembangan Perpustakaan Perguruan Tinggi dalam Memenuhi

Kebutuhan Informasi di Era Digital (Sebuah Pandangan Sosiologis atas Fenomena

Spiritual Seekers di Dunia Maya). Jurnal Libraria, Vol. 4, No. 1. Retrieved From:

http://journal.stainkudus.ac.id/index.php/Libraria/article/d ownload/1243/pdf

pada 29 April 2019

Subrata, Gatot. Perpustakaan Digital. Retrieved From:

http://digilib.um.ac.id/images/stories/pustakawan/kargto/P erpustakaan\%20Digital.pdf

Suherman. (2018). Strategi Pengembangan Layanan Perpustakaan dalam Menggunakan

Media Sosial di Perguruan Tinggi. Jurnal Iqra', Vol. 12, No. 02. Retrieved From:

http://jurnal.uinsu.ac.id/index.php/iqra/article/download/3 $979 / 1965$ 